Biol. Stud. 2021; 15(4): 25-36 • DOI: https://doi.org/10.30970/sbi.1504.661

www.http://publications.Inu.edu.ua/journals/index.php/biology

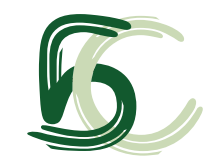

UDC: [[577.1+576.7]-043.7:599.323.45.047-032.35]]+613.6.027

\title{
BIOCHEMICAL AND HISTOLOGIC CHANGES IN ALBINO RATS IN RESPONSE TO CHARCOAL POWDER EXPOSURE
}

\author{
O. E. Oriakpono 1 1, C. Anuforo ${ }^{2}$, \\ E. E. Nduonofit ${ }^{1}$, B. K. Deeyah ${ }^{1}$, M. C. Ekeke® \\ ${ }^{1}$ University of Port Harcourt, P. M. B. 5323, Port Harcourt, Rivers State, Nigeria \\ ${ }^{2}$ Institute of Biochemistry, Molecular Biology and Biotechnology, University of Colombo, Sri Lanka \\ Oriakpono, O. E., Anuforo, C., Nduonofit, E. E., Deeyah, B. K., \& Ekeke, M. C. (2021). Biochemical \\ and histologic changes in albino rats in response to charcoal powder exposure. Studia Biologica, \\ 15(4): 25-36 • DOI: https://doi.org/10.30970/sbi.1504.661
}

Background. In developing and under-developed countries, charcoal production predisposes workers to charcoal dust. This is a common occurrence as workers in this field are not properly protected and as such are exposed to charcoal dust through inhalation and skin contact. Charcoal comprises many components such as polycyclic aromatic hydrocarbons (PAHs). Due to the possible health risk associated with such exposure, this study was designed to determine the effects of charcoal powder of particle size $125 \mu \mathrm{m}-150 \mu \mathrm{m}$ on certain biomarkers in male albino rats. Albino rats were used because of their similar physiology to humans.

Materials and Methods. 20 albino rats weighing between $250 \mathrm{~g}$ and $300 \mathrm{~g}$ were used for this study; they were randomly distributed in 4 groups ( 5 rats each) and the charcoal powder was incorporated into their feed at different percentages; control, group 1 (10\% charcoal), group 2 (30\% charcoal) and group 3 (charcoal powder bedding) for 50 days. Using standard procedures and methods, the following parameters were tested: Hematological parameters, semen parameters, liver enzymes, renal function, hormones and lung histology.

Results. The results indicated a decrease in the level of liver enzymes AST (IU/L) and ALT (IU/L) in group 1, group 2 and group 3 when compared to the control with the lowest value of $48.75 \mathrm{IU} / \mathrm{L}$ and $11.50 \mathrm{IU} / \mathrm{L}$ respectively recorded in group 2 . Prolactin (mIU/L) had mean values of 1.73, 1.30 and 1.83 in group 1 , group 2 and group 3 respectively while the control was 2.10 . Testosterone $(\mathrm{nmol} / \mathrm{L})$ had a mean value of $1.18,0.53$ and 0.25 in group 1 , group 2 and group 3 , respectively, while the control was 0.90 with

() 2021 O. E. Oriakpono et al. Published by the Ivan Franko National University of Lviv on behalf of Біологічні Студії / Studia Biologica. This is an Open Access article distributed under the terms of the Creative Commons Attribution 4.0 License which permits unrestricted reuse, distribution, and reproduction in any medium, provided the original work is properly cited.

ISSN 1996-4536 (print) • ISSN 2311-0783 (on-line) • Біологічні Студії / Studia Biologica • 2021 • Том 15 / № 4 • С. 25-36 
a significant difference $(P<0.05)$. Creatinine $(\mu \mathrm{mol} / \mathrm{L})$ increased in group 1 and group 2 with a slight reduction in group 3 when compared to control (1.04) with a value of 1.35, 1.40 and 1.23 , respectively. Total sperm count $\left(\times 10^{5} / \mathrm{mL}\right)$ had a mean value of 58.33 , 50.00 and 43.25 in group 1 , group 2 and group 3, respectively, while the control was 100.50. The lung histology for the treated groups revealed infiltration of inflammatory cells and thickening of inter-alveolar walls.

Conclusion. Long term exposure to charcoal powder through nasal or oral route had serious effects on rats' health, such as kidney damages, inflammation of the lungs and decrease in fertility in males primarily due to the presence of PAHs in charcoal.

Keywords: charcoal, hormones, infertility, lung inflammation, polyaromatic hydrocarbon

\section{INTRODUCTION}

Charcoal is an incompletely burnt wood commonly used for fires because it burns more slowly, hotter and cleaner than wood (less smoky). It is derived from organic material and has a high carbon content with a chemical composition similar to coal dust (Eileen et al., 2009). Approximately, 30\% of wood harvested for fuel in Africa is for charcoal production (Ubogu \& Odokuma, 2019). The production process of charcoal predisposes the workers to charcoal dust (Tzanakis et al., 2001); this implies that workers from developing countries who do not frequently use Personal Protective Equipment (PPEs) will be exposed to charcoal dust through inhalation and skin contact. Research has confirmed that exposures to fine particulate matter is directly associated with a reduction in lung capacity and poor respiratory health, including chronic lung diseases such as pneumoconiosis and chronic obstruction pulmonary disease (COPD) among individuals occupationally exposed to charcoal (Mamuya et al., 2007). Other inferences on possible health effect is associated with the usage of charcoal as biomass fuel (Diaz et al., 2006). Local fish smoking, corn roasting and other local food processing methods that rely on the use of charcoal as a source of fuel exposes the food to charcoal dust. Charcoal comprises many components that are irritant and genotoxic, such as nitrogen and sulphur oxides, benzene, methanol, styrene, phenols, naphthalene, aldehydes, organic acids, and polycyclic aromatic hydrocarbons (PAHs) (Larson \& Koenig, 1994). Extracts of charcoal have also been reported by other authors to contain PAHs (Monzer et al., 2008). PAHs are organic compounds containing only carbon and hydrogen that are composed of multiple aromatic rings (organic rings in which the electrons are delocalized), the structure of a PAH determines whether the individual compound is carcinogenic or not. Some carcinogenic PAHs are genotoxic and induce mutations that initiate cancer; others are not genotoxic but affect cancer promotion or progression (Baird et al., 2005). In laboratory experiments, animals exposed to certain PAHs have shown increased development of plagues (atherogenesis) within arteries (Ramos \& Moorthy, 2005). A research carried out to determine the concentration of PAH in charcoal showed that charcoal had high concentration of $\mathrm{PAH}$ in compounds like acenaphthylene, acenephthene, flourene, anthracene, flourathene and dibenzo(a,h)anthracene (Silva et al., 2011). In under-developed and developing countries, workers in charcoal production centers and establishments are frequently exposed to large amounts of charcoal dust through inhalation due to lack or non-use of PPEs; while local users that employ charcoal as biofuel in roasting and smoking foods also accidentally expose our foods to

ISSN 1996-4536 (print) • ISSN 2311-0783 (on-line) • Біологічні Студії / Studia Biologica • 2021 • Том 15 / № 4 • C. 25-36 
charcoal dust contamination. It is therefore important to determine the effects of such exposures on the body. Hence, this study is aimed at determining the effects of charcoal dust on male albino rats through oral and nasal routes using biomarkers considering the fact that albino rats share similar physiology with humans.

\section{MATERIALS AND METHODS}

Experimental design. Completely randomized design (CRD) was adopted in this study. 20 albino rats were used for this study and the rats were randomly distributed and placed in four groups, each containing five animals. Each rat weighed between $250 \mathrm{~g}$ to $300 \mathrm{~g}$. The animals were kept in circular plastic cages of about $60 \mathrm{~cm}$ in circumference with a depth of $20 \mathrm{~cm}$ which were covered with wire gauze, beddings of wood shaving which were replaced twice weekly.

Treatment of animals. The rats were fed with standard feed and water twice daily and after a week of acclimatization, charcoal powder (particle size $125 \mu \mathrm{m}-150 \mu \mathrm{m}$ ) was incorporated into the feed of the animals at different percentages while charcoal powder of particle size $125 \mu \mathrm{m}-150 \mu \mathrm{m}$ was used as the bedding for the last group. The groups were:

Control: Normal Feed and Normal Bedding.

Group 1: $10 \%$ charcoal powder $(5.635 \mathrm{~kg}$ of feed $+0.625 \mathrm{~kg}$ charcoal powder) with Normal Bedding.

Group 2: $30 \%$ charcoal powder $(4.375 \mathrm{~kg}$ of feed $+1.875 \mathrm{~kg}$ charcoal powder) with Normal Bedding.

Group 3: Normal Feed with charcoal powder as bedding (charcoal used as rat bedding to ensure inhalation).

The treatment was for a period of 50 days before biochemical and histologic analysis.

Biochemical analysis. The white blood cells (WBC) were determined by the improved Neubauerhaemocytometer while the Shilling method of differential leucocyte count was used to determine the distribution of the various white blood cells according to the EMS (EMS, 2021). Activities of alanine transaminase (ALT) and aspartate transaminase (AST) in the plasma were determined using Reitman and Frankel method (Reitman \& Frankel, 1957). Testosterone levels were determined using Testosterone enzyme immunological test kit (catalogue number BC 115), while prolactin levels were determined according to the method of Jeffcoate et al. (1986). Semen was collected from the sperm duct by maceration on the glass slide and the analysis procedure was done according to Ochie and Kolhatkar (2000) and the sperm was counted under a light microscope (Zaneveld \& Polakosk, 1977). Standard procedures for lung histology (fixing and staining) was adopted according to Morton and Snider (2017) and serum creatinine was analyzed by means of the Kinetic Jaffe's method on a SYNCHRON CX system analyzer (SYNCHRON, Los Angeles, CA).

Method of data analysis. Statistical analysis was carried out using one-way Analysis of Variance (ANOVA) and Duncan test using Assistat en (2017). The data were expressed as mean \pm standard deviation, results were considered significant when $p$ value was less than $0.05(P<0.05)$.

\section{RESULTS AND DISCUSSION}

Effects of charcoal powder on hematological parameters of blood and renal function of albino rats through oral/inhalation administration. The effects of oral

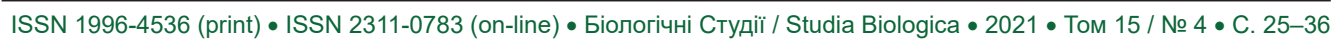


administration and inhalation of charcoal on the hematological parameters in male albino rats are presented in Table 1. In week eight, the white blood cells for the treated groups had values of $5.47\left(\times 10^{9} / \mathrm{L}\right), 4.88\left(\times 10^{9} / \mathrm{L}\right)$ and $6\left(\times 10^{9} / \mathrm{L}\right)$ for groups 1,2 and 3 , respectively, while the control had $4.45\left(\times 10^{9} / \mathrm{L}\right)$. For the neutrophils, the treated groups had values of $44.33 \%, 27.5 \%$ and $25.75 \%$ for groups 1,2 and 3 respectively, while the control had $30.5 \%$. For the lymphocyte, the treated groups had values of $50.67 \%$, $66.25 \%$ and $64.5 \%$ for groups 1,2 and 3 respectively, while the control had $65.5 \%$. The result for monocyte showed that, the treated groups had values of $2 \%, 3.5 \%$ and $4.75 \%$ for groups 1, 2 and 3 respectively, while the control had $1.5 \%$. For Eosinophil, the treated groups had values of $3 \%, 2.75 \%$ and $5 \%$ for groups 1,2 and 3 , respectively, while the control had $3.5 \%$.

Table 1. Hematological parameters and indicators of renal function in rats treated for 8 weeks by ingestion and inhalation with $10 \%, 30 \%$ and beddings of charcoal

Таблиця 1. Гематологічні показники та функція нирок у щурів, які отримували 10 \%, 30 \% деревного вугілля із їжею або вдихали з підстилки впродовж 8 тижнів

\begin{tabular}{|c|c|c|c|c|c|c|c|}
\hline Group & $\begin{array}{c}\text { White } \\
\text { blood cells } \\
\left(\times 10^{\%} / \mathrm{L}\right)\end{array}$ & $\begin{array}{c}\text { Neutrophilis } \\
(\%)\end{array}$ & $\begin{array}{c}\text { Lymphocyte } \\
(\%)\end{array}$ & $\begin{array}{c}\text { Monocyte } \\
(\%)\end{array}$ & $\begin{array}{c}\text { Eosinophil } \\
(\%)\end{array}$ & $\begin{array}{c}\text { Basophils } \\
(\%)\end{array}$ & $\begin{array}{c}\text { Creatinine } \\
(\mu \mathrm{mol} / \mathrm{L})\end{array}$ \\
\hline Control & $4.45 \pm 0.07^{\mathrm{a}}$ & $30.50 \pm 0.71^{\mathrm{b}}$ & $65.50 \pm 0.71^{\mathrm{a}}$ & $1.50 \pm 0.71^{\mathrm{a}}$ & $3.50 \pm 0.71^{\mathrm{a}}$ & 1 & $1.04 \pm 0.00^{\mathrm{a}}$ \\
\hline Group 1 & $5.47 \pm 1.27^{\mathrm{a}}$ & $44.33 \pm 5.13^{\mathrm{a}}$ & $50.67 \pm 4.04^{\mathrm{b}}$ & $2.00 \pm 2.65^{\mathrm{a}}$ & $3.00 \pm 1.73^{\mathrm{a}}$ & 0 & $1.35 \pm 0.29^{\mathrm{a}}$ \\
\hline Group 2 & $4.88 \pm 0.85^{\mathrm{b}}$ & $27.50 \pm 4.93^{\mathrm{b}}$ & $66.25 \pm 3.86^{\mathrm{a}}$ & $3.50 \pm 2.52^{\mathrm{a}}$ & $2.75 \pm 1.71^{\mathrm{a}}$ & 0 & $1.40 \pm 0.42^{\mathrm{a}}$ \\
Group 3 & $6.00 \pm 1.77^{\mathrm{b}}$ & $25.75 \pm 5.12^{\mathrm{b}}$ & $64.50 \pm 6.14^{\mathrm{a}}$ & $4.75 \pm 2.06^{\mathrm{a}}$ & $5.00 \pm 0.82^{\mathrm{a}}$ & 0 & $1.23 \pm 0.54^{\mathrm{a}}$ \\
\hline
\end{tabular}

Comments: ${ }^{a-d}$ - different letters in the same column indicate significant difference $(P<0.05)$

Примітки: $\quad$ a-d - різні букви в одному стовпці вказують на значну різницю $(P<0,05)$

From the results obtained, the percentage of white blood cell count of the treated groups (group 1, 2 and 3) increased when compared to the control. The increased mean value of group 1 was not significant $(P>0.05)$ when compared to the control indicating that the amount of charcoal ingested was not at a level that can induce a significant immune response. The mean values of groups 2 and 3 increased significantly $(P<0.05)$ when compared to the control. This increment (group 2 and 3 ) clearly implies that there is an inducement of an immune response due to the presence of PAH contained in the charcoal. Physiologically, an increase in the white blood cell count is a known indicator that there is an inflammatory reaction and infection. PAH have been reported to indirectly cause inflammation; although this was reported to be possible through atmospheric exposure. This effect is achieved via what is known as immune-potentiation that results in an increment in the secretion of cytokines thereby causing inflammation (Abdel-Shafy \& Mansour, 2016). PAH was also reported to have immune suppressing effect. In addition, the suppression of the immune system by PAH has been reported to be a possible cancer inducing mechanism as dibenzo(a,h)anthracene is among the identified PAH that is found in charcoal extract which have been reported to be carcinogenic(USEPA, 1984; ATSDR, 1995; Silva et al., 2011; Gao \& Burchiel, 2014; Rengarajana et al., 2015). The neutrophil was observed to be higher than the control in group 1 while in group 2 and group 3, a lower value with no significant difference $(P>0.05)$ was ob-

ISSN 1996-4536 (print) • ISSN 2311-0783 (on-line) • Біологічні Студії / Studia Biologica • 2021 • Том 15 / № 4 • C. 25-36 
served when compared to the control. The monocytes also increased in the treated groups, showing that the chemicals in the charcoal powder are interacting with the body immune system.

The mean creatinine values for the treated groups were $1.35 \mu \mathrm{mol} / \mathrm{L}, 1.40 \mu \mathrm{mol} / \mathrm{L}$ and $1.23 \mu \mathrm{mol} / \mathrm{L}$ for groups 1,2 and 3, respectively, while the control had $1.04 \mu \mathrm{mol} / \mathrm{L}$. The serum creatinine level was recorded to be higher in the treated group (group 1, 2 and 3) when compared to the control, although not significantly $(P>0.05)$. It is an indicator of kidney damage. This is buttressed by a study that revealed that adults that are occupationally exposed to PAH have increased level of oxidative stress biomarkers and this increase in oxidative stress causes kidney dysfunction which consequently damages the cells and tissues of the kidney (Farzan et al., 2016).

Effect of charcoal powder on liver activities of albino rats. Table 2 shows the mean values of AST in control, groups 1, 2, 3 as $89.00 \mathrm{IU} / \mathrm{L}, 89.00 \mathrm{IU} / \mathrm{L}, 48.75 \mathrm{IU} / \mathrm{L}$ and $68.50 \mathrm{IU} / \mathrm{L}$ respectively. ALT had mean values of $67.00 \mathrm{IU} / \mathrm{L}, 65.00 \mathrm{IU} / \mathrm{L}, 24.25 \mathrm{IU} / \mathrm{L}$, $11.50 \mathrm{IU} / \mathrm{L}$ and $13.50 \mathrm{IU} / \mathrm{L}$ for control, group 1, group 2 and group 3, respectively. The liver enzymes AST and ALT which play an essential role in protein metabolism in the body were observed to be lower than the control when the treated group is compared with the control. Even though low levels of ALT and AST does not directly imply damages to the liver, it is however a sign of severe decline in kidney function when the levels are extremely low as we recorded in the experiment. This directly implies that due to the presence of $\mathrm{PAH}$, there is an induced high oxidative stress which consequently affected the kidney function negatively causing kidney dysfunction as can be seen in the extremely low levels of ALT and AST and a corresponding high level of serum creatinine due to exposure to PAH in diet and through the nasal route (Sette \& Lopes, 2015).

Table 2. Effect of charcoal on liver activities of albino rats treated for 8 weeks by ingestion and inhalation with $10 \%, 30 \%$ and beddings of charcoal

Таблиця 2. Функціонування печінки щурів-альбіносів у разі внесення $10 \%, 30$ \% деревного вугілля у харчовий раціон або його вдихання 3 підстилки впродовж 8 тижнів

\begin{tabular}{c|c|c}
\hline Group & $\begin{array}{c}\text { SGOT (AST) } \\
(\text { IU/L) }\end{array}$ & $\begin{array}{c}\text { SGPT (ALT) } \\
(I U / L)\end{array}$ \\
\hline Control & $89.00 \pm 0.00^{\mathrm{a}}$ & $67.00 \pm 0.00^{\mathrm{a}}$ \\
\hline Group 1 & $89.00 \pm 0.00^{\mathrm{a}}$ & $24.25 \pm 7.27^{\mathrm{a}}$ \\
Group 2 & $48.75 \pm 46.49^{\mathrm{a}}$ & $11.50 \pm 8.81^{\mathrm{a}}$ \\
\hline Group 3 & $68.50 \pm 47.34^{\mathrm{a}}$ & $13.50 \pm 11.15^{\mathrm{a}}$ \\
\hline
\end{tabular}

Comments: ${ }^{a-d}$ - different letters in the same column indicate significant difference $(P<0.05)$

Примітки: $\quad$ a-d - різні букви в одному стовпці вказують на значну різницю $(P<0,05)$

Effect of charcoal powder on hormones concentration in albino rats. Prolactin had mean values of $2.10 \mathrm{mIU} / \mathrm{L}, 1.73 \mathrm{mIU} / \mathrm{L}, 1.30 \mathrm{mIU} / \mathrm{L}$ and $18.30 \mathrm{mIU} / \mathrm{L}$ for control, group 1, group 2 and group 3, respectively (Table 3 ). Testosterone had mean values of $0.90 \mathrm{nmol} / \mathrm{L}, 1.18 \mathrm{nmol} / \mathrm{L}, 0.53 \mathrm{nmol} / \mathrm{L}$ and $0.25 \mathrm{nmol} / \mathrm{L}$ for control, group 1 , group 2 and group 3, respectively (Table 3 ). The hormones were also adversely affected, with low prolactin level recorded in the treated groups compared to the control, thereby indicating

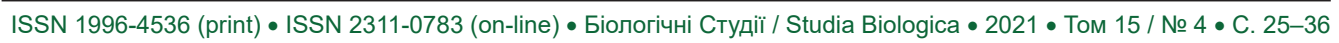


that the charcoal also had a negative effect on prolactin. PAH can also compromise spermatogenesis function and alter endocrine hormone levels. It was also observed that testosterone decreased in the treated groups when compared to the control with the exception of group 1; this has been linked to PAH exposure as reported by Jeng and Yu (2008). Low testosterone level actually leads to low sex drive, reduction in penis size, muscle shrinkage, growing of the belly, memory loss and weakened bones (Cindy, 2016).

Table 3. Effect of charcoal on hormones concentration of albino rats treated for 8 weeks by ingestion and inhalation with $10 \%, 30 \%$ and beddings of charcoal

Таблиця 3. Концентрація гормонів у щурів-альбіносів у разі внесення $10 \%, 30$ \% деревного вугілля у харчовий раціон або його вдихання з підстилки впродовж 8 тижнів

\begin{tabular}{ccc}
\hline Group & Prolactin $(\mathrm{mlU} / \mathrm{L})$ & Testosterone $(\mathrm{nmol} / \mathrm{L})$ \\
\hline Control & $2.10 \pm 0.00^{\mathrm{a}}$ & $0.90 \pm 0.00^{\mathrm{a}}$ \\
Group 1 & $1.73 \pm 0.28^{\mathrm{a}}$ & $1.18 \pm 0.32^{\mathrm{a}}$ \\
Group 2 & $1.30 \pm 0.14^{\mathrm{a}}$ & $0.53 \pm 1.73^{\mathrm{ab}}$ \\
Group 3 & $1.83 \pm 0.10^{\mathrm{a}}$ & $0.25 \pm 0.17^{\mathrm{b}}$ \\
\hline
\end{tabular}

Comments: ${ }^{a-d}$ - different letters in the same column indicate significant difference $(P<0.05)$

Примітки: $\quad$ a-d - різні букви в одному стовпці вказують на значну різницю $(P<0,05)$

Effects of charcoal powder on semen parameters in albino rats. The effects of oral and inhalation administration of charcoal on semen parameters of male albino rats are presented in Table 4. The motile cell for the treated groups had values of $91.67 \%$, $60.00 \%$ and $80.00 \%$ for groups 1, 2 and 3, respectively, while the control had $99.50 \%$ In the active cells, the treated groups had values of $80.00 \%, 48.75 \%$ and $72.50 \%$ for groups 1, 2 and 3, respectively, while the control had $95.50 \%$. In the viable cell, the treated groups had values of $95.33 \%, 94.50 \%$ and $95.75 \%$ for groups 1, 2 and 3, respectively, while the control had $91.50 \%$. In the total sperm cell count, the treated groups had values of $58.33\left(\times 10^{5} / \mathrm{mL}\right), 50.00\left(\times 10^{5} / \mathrm{mL}\right)$ and $43.25\left(\times 10^{5} / \mathrm{mL}\right)$ for groups 1,2 and 3 , respectively, while the control had $100.50\left(\times 10^{5} / \mathrm{mL}\right)$.

There was a reduction in the values of motile cells in groups 1, 2 and 3 when compared to the control and all three groups had no significant difference compared to the control $(P>0.05)$. The sperm cells were also adversely affected by the charcoal treatment. The reason for this adverse effect recorded in the semen parameters is directly related to the presence of PAHs, which has the capacity to induce oxidative stress, and the testicles being very sensitive to oxidative stress thereby leading to the corresponding disruption of spermatogenesis (Asadi et al., 2017). Similar negative effect was suggested in a recent finding which proposes that exposure to PAHs disrupts sperm DNA and thereby interferes with human male fertility (Han et al., 2011). A study by Xia et al. (2009) revealed that exposure to PAHs at environmental levels is associated with an increased risk of male idiopathic infertility. Hsu et al. (2006) reported that the ambient $\mathrm{PAH}$ levels of occupationally exposed individuals are associated with decreased spermatozoa quality. Experimental studies in rats indicate that PAH exposure is negatively correlated with daily sperm production and sperm motility (Ramesh et al., 2008).

ISSN 1996-4536 (print) • ISSN 2311-0783 (on-line) • Біологічні Студії / Studia Biologica • 2021 • Том 15 / № 4 • C. 25-36 
Table 4. Effects of charcoal exposure on semen parameters of albino rats treated for 8 weeks by ingestion and inhalation with $10 \%, 30 \%$ and beddings of charcoal

Таблиця 4. Параметри сперми щурів-альбіносів у разі внесення 10 \%, 30 \% деревного вугілля у харчовий раціон або його вдихання 3 підстилки впродовж 8 тижнів

\begin{tabular}{c|c|c|c|c|c|c|c}
\hline Group & $\begin{array}{c}\text { Motile cell } \\
(\%)\end{array}$ & $\begin{array}{c}\text { Active cell } \\
(\%)\end{array}$ & $\begin{array}{c}\text { Sluggish } \\
\text { cell }(\%)\end{array}$ & $\begin{array}{c}\text { Dwad cell } \\
(\%)\end{array}$ & $\begin{array}{c}\text { Viable cell } \\
(\%)\end{array}$ & $\begin{array}{c}\text { Non viable } \\
\text { cell }(\%)\end{array}$ & $\begin{array}{c}\text { Total sperm } \\
\text { cell count } \\
\left(\times 10^{5} / \mathrm{mL}\right)\end{array}$ \\
\hline Control & $99.50 \pm 0.71^{\mathrm{a}}$ & $95.50 \pm 0.71^{\mathrm{a}}$ & $4.50 \pm 0.71^{\mathrm{a}}$ & $1.50 \pm 0.71^{\mathrm{a}}$ & $91.50 \pm 0.71^{\mathrm{b}}$ & $9.50 \pm 0.71^{\mathrm{a}}$ & $100.50 \pm 0.71^{\mathrm{a}}$ \\
Group 1 & $91.67 \pm 2.89^{\mathrm{a}}$ & $80.00 \pm 8.66^{\mathrm{a}}$ & $11.67 \pm 5.77^{\mathrm{a}}$ & $8.33 \pm 2.89^{\mathrm{a}}$ & $95.33 \pm 2.08^{\mathrm{a}}$ & $4.67 \pm 2.08^{\mathrm{b}}$ & $58.33 \pm 15.28^{\mathrm{b}}$ \\
Group 2 & $60.00 \pm 31.62^{\mathrm{a}}$ & $48.75 \pm 33.51^{\mathrm{a}}$ & $11.25 \pm 9.47^{\mathrm{a}}$ & $40.00 \pm 31.62^{\mathrm{a}}$ & $94.50 \pm 0.58^{\mathrm{a}}$ & $5.50 \pm 0.58^{\mathrm{b}}$ & $50.00 \pm 3.36^{\mathrm{b}}$ \\
\hline Group 3 & $80.00 \pm 20.41^{\mathrm{a}}$ & $72.50 \pm 29.01^{\mathrm{a}}$ & $8.75 \pm 7.50^{\mathrm{a}}$ & $20.00 \pm 20.41^{\mathrm{a}}$ & $95.75 \pm 1.26^{\mathrm{a}}$ & $4.25 \pm 1.26^{\mathrm{b}}$ & $43.25 \pm 5.38^{\mathrm{b}}$ \\
\hline
\end{tabular}

Comments: ${ }^{a-d}$ - different letters in the same column indicate significant difference $(P<0.05)$

Примітки: $\quad$ a-d - різні букви в одному стовпці вказують на значну різницю $(P<0,05)$

Effect of Charcoal powder on lung histology of albino rats treated by inhalation. The lung histology revealed that exposure to charcoal powder or dust had a negative effect on the lungs (Fig. 3-4). The alveolar sacs decreased in number and size compared to control group (Fig. 1-2), blood vessels were also observed to be congested, and infiltration of inflammatory cells were also observed in the treated group. The inter alveolar walls were also thickened when compared to the control. The results of the lung histology showed a distorted lung which means that charcoal dust is harmful. Long term exposure to PAH have been known to lead to decreased immune function and lung function (Khairy et al., 2009). Inhalation of PAHs have also been linked to the increased risk of lung cancer (Kim et al., 2013). When particles of charcoal are inhaled, bearing in mind that dibenzo(a,h)anthracene which is among the PAHs reported to be present in charcoals is a known carcinogen, there is an increased risk of lung cancer amidst other respiratory abnormalities that have been reported to be caused by inhaling charcoal dust and particles (USEPA, 1984; ATSDR, 1995; Silva et al., 2011; Rengarajana et al., 2015).

Effect of Charcoal powder on lung histology of albino rats treated by inhalation.

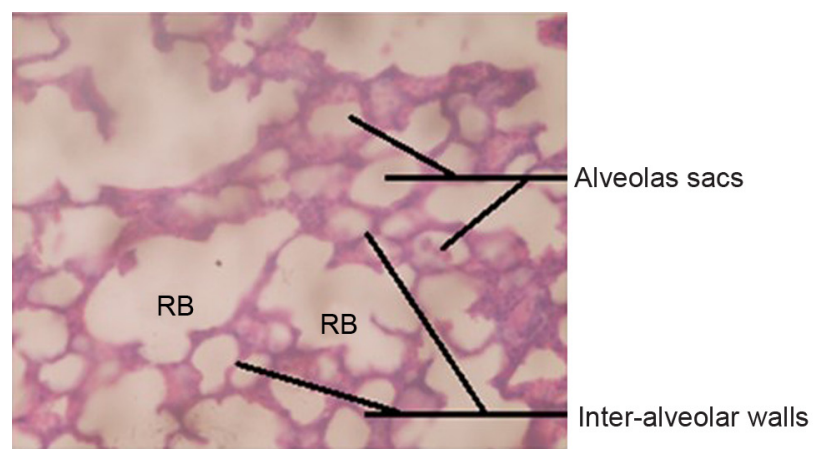

Fig. 1. Lung Histology of control a: RB - respiratory bronchioles

Рис. 1. Гістологія легень у контролі а: RB - дихальні бронхіоли

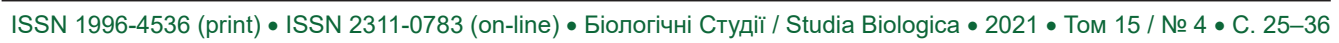




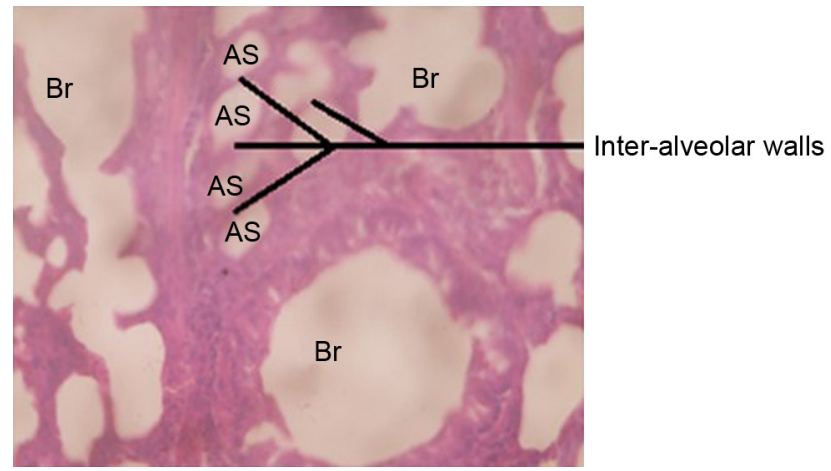

Fig. 2. Lung Histology of control b: $\mathrm{AS}$ - alveolar sacs; $\mathrm{Br}$ - bronchi

Рис. 2. Гістологія легень у контролі b: AS - альвеолярні мішки; $\mathrm{Br}$ - бронхи
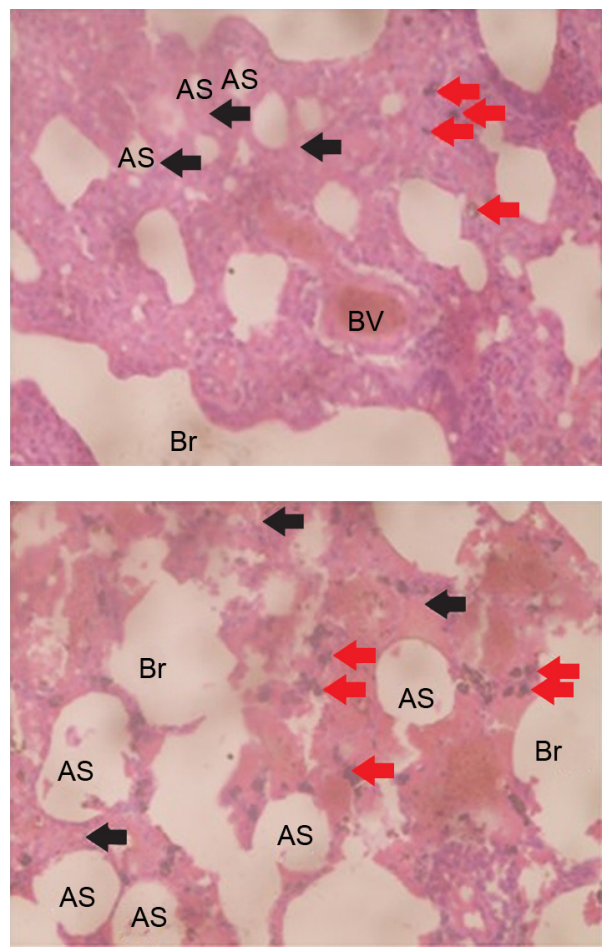

Fig. 3. Lung histology of group 3a: AS - alveolar sacs; $\mathrm{Br}$ - bronchi; DV - blood vessels; red arrow infiltration of inflammatory cells; black arrow thickened inter alveolar walls

Рис. 3. Гістологія легенів групи За: AS - альвеолярні мішечки; $\mathrm{Br}$ - бронхи; BV - кровоносні судини; червона стрілка - інфільтрація запальних клітин; чорна стрілка - потовщені міжальвеолярні стінки

Fig. 4. Lung histology of group $3 b$ : AS - alveolar sacs; $\mathrm{Br}$ - bronchi; red arrow - infiltration of inflammatory cells; black arrow - thickened inter alveolar walls

Рис. 4. Гістологія легенів групи 3b: AS - альвеолярні мішечки; $\mathrm{Br}$ - бронхи; червона стрілка - інфільтрація запальних клітин; чорна стрілка - потовщені міжальвеолярні стінки

\section{CONCLUSION}

This research revealed that exposure to charcoal powder has toxic effects on albino rats after such exposure and considering the similar physiology with humans as established in literature in the medical sciences, similar effect may occur in humans when subjected to chronic exposure. The results of this exposure include; kidney toxicity, lower prolactin and testosterone levels, lung histology abnormalities, as well as an adverse effect on reproductive capabilities of animals. This toxicity is due to the PAHs content of the charcoal extracts and it is therefore important to ensure adequate protection from long term exposure to charcoal powder and avoid

ISSN 1996-4536 (print) • ISSN 2311-0783 (on-line) • Біологічні Студії / Studia Biologica • 2021 • Том 15 / № 4 • С. 25-36 
ingestion especially at large amounts. As usual, workers in charcoal plants not using PPEs in under-developed and developing countries are vulnerable to such exposure while the consumption of locally processed foods utilizing charcoal as energy source may expose the food materials/consumers to some level of charcoal powder and its associated combustion product.

\section{ACKNOWLEDGMENTS AND FUNDING SOURCES}

This study did not receive any particular grant from any financial organizations in the state, commercial, or non-commercial sectors.

\section{COMPLIANCE WITH ETHICAL STANDARDS}

Conflict of Interest: The authors declare that the research was conducted in the absence of any commercial or financial relationships that could be construed as a potential conflict of interest.

Human Rights: This article does not contain any studies with human subjects performed by any of the authors.

Animal studies: All international, national and institutional guidelines for the care and use of laboratory animals were followed.

\section{AUTHOR CONTRIBUTIONS}

Conceptualization, [O.E.O.; A.C.]; methodology, [O.E.O.; A.C.]; validation, [O.E.O.]; formal analysis, [O.E.O.; A.C.; N.E.E.; D.B.K.; E.M.C.]; investigation, [O.E.O.; A.C.; N.E.E.; D.B.K.; E.M.C.]; resources, [A.C.; N.E.E.; D.B.K.; E.M.C.]; data curation, [N.E.E.; A.C.]; writing - original draft preparation, [O.E.O.]; writing - review and editing, [O.E.O.; A.C.; N.E.E.]; visualization, [O.E.O.; N.E.E.; A.C.]; supervision, [O.E.O.]; project administration, [O.E.O,; A.C.; N.E.E.]; funding acquisition, [D.B.K.; E.M.C.].

All authors have read and agreed to the published version of the manuscript.

\section{REFERENCES}

Abdel-Shafy, H. I., \& Mansour, M. S. M. (2016). A review on polycyclic aromatic hydrocarbons: Source, environmental impact, effect on human health and remediation. Egyptian Journal of Petroleum, 25(1), 107-123. doi:10.1016/j.ejpe.2015.03.011

Crossref • Google Scholar

Agency for Toxic Substances and Disease Registry (ATSDR), (1995). Toxicological profile for polycyclic aromatic hydrocarbons (PAHs). Atlanta, GA: U.S. Department of Health and Human Services, Public Health Service.

Asadi, N., Bahmani, M., Kheradmand, A., \& Rafieian-Kopaei, M. (2017). The impact of oxidative stress on testicular function and the role of antioxidants in improving it: A review. Journal of Clinical and Diagnostic Research, 11(5), IE01-IE05. doi:10.7860/jcdr/2017/23927.9886 Crossref $\bullet$ PubMed $\bullet$ PMC $\bullet$ Google Scholar

Baird, W. M., Hooven, L. A., \& Mahadevan, B. (2005). Carcinogenic polycyclic aromatic hydrocarbonDNA adducts and mechanism of action. Environmental and Molecular Mutagenesis, 45(2-3), 106-114. doi:10.1002/em.20095

Crossref $\bullet$ PubMed $\bullet$ Google Scholar

Cindy, K. (2016). Health effects of low testosterone. Available at: https://www.google.com.ng/ amp/s/www.menshealth.com/health/amp19533454/effects-of-low-testosterone/

Diaz, J. V., Koff, J., Gotway, M. B., Nishimura, S., \& Balmes, J. R. (2006). Case report: a case of wood-smoke - related pulmonary disease. Environmental Health Perspectives, 114(5), 759-762. doi:10.1289/ehp.8489

Crossref • PubMed $\bullet$ PMC • Google Scholar

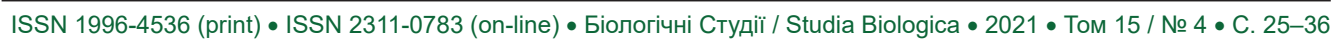


Eileen, D. K., Matthew, W. W., Randall, J. S., Van, V., \& Francis, H. Y. G. (2009). Contributions of dust exposure and cigarette smoking to emphysema severity in coal miners in the United States. American Journal of Respiratory and Critical Care Medicine, 180(3), 257-264. doi:10.1164/rccm.200806-840oc

Crossref $\bullet$ PubMed $\bullet$ Google Scholar

Electron Microscopy Sciences (EMS), (2021). Neubauer Haemocytometry. Retrieved on 29 August, $2021 \mathrm{from} \mathrm{https://www.emsdiasum.com/microscopy/technical/datasheet/68052-14.aspx}$

Farzan, S. F., Chen, Y., Trachtman, H., \& Trasande, L. (2016). Urinary polycyclic aromatic hydrocarbons and measures of oxidative stress, inflammation and renal function in adolescents: NHANES 2003-2008. Environmental Research, 144, 149-157. doi:10.1016/j.envres.2015.11.012 Crossref • PubMed • PMC • Google Scholar

Gao, J., \& Burchiel, S. W. (2014). Genotoxic mechanisms of PAH-induced immunotoxicity. Molecular Immunotoxicology, 245-262. doi:10.1002/9783527676965.ch12

Crossref • Google Scholar

Han, X., Zhou, N., Cui, Z., Ma, M., Li, L., Cai, M., Li, Y., Lin, H., Ao, L., Liu, J., \& Cao, J. (2011). Association between urinary polycyclic aromatic hydrocarbon metabolites and sperm DNA damage: A population study in Chongqing, China. Environmental Health Perspectives, 119(5), 652-657. doi:10.1289/ehp.1002340

Crossref $\bullet$ PubMed $\bullet$ PMC $\bullet$ Google Scholar

Hsu, P. C., Chen, I. Y., Pan, C. H., Wu, K. Y., Pan, M. H., \& Chen, J. R. (2006). Sperm DNA damage correlates with polycyclic aromatic hydrocarbons biomarker in coke-oven workers. International Archives of Occupational and Environmental Health, 79(5), 349-356. doi:10.1007/s00420-005-0066-3

Crossref $\bullet$ PubMed $\bullet$ Google Scholar

Jeffcoate, S. L., Bacon, R. R. A., Beastall, G. H., Diver, M. J., Franks, S., \& Seth, J. (1986). Assay for prolactin: Guidelines for the provision of a clinical biochemistry service. Annals of Clinical Biochemistry: International Journal of Laboratory Medicine, 23(6), 638-651. doi: $10.1177 / 000456328602300603$

Crossref $\bullet$ PubMed $\bullet$ Google Scholar

Jeng, H. A., \& Yu, L. (2008). Alteration of sperm quality and hormone levels by polycyclic aromatic hydrocarbons on airborne particulate particles. Journal of Environmental Science and Health, Part A, 43(7), 675-681. doi:10.1080/10934520801959815 Crossref • Google Scholar

Khairy, M. A., Kolb, M., Mostafa, A. R., EL-Fiky, A., \& Bahadir, M. (2009). Risk assessment of polycyclic aromatic hydrocarbons in a Mediterranean semi-enclosed basin affected by human activities (Abu Qir Bay, Egypt). Journal of Hazardous Materials, 170(1), 389-397. doi:10.1016/j.jhazmat.2009.04.084

Crossref $\bullet$ PubMed $\bullet$ Google Scholar

Kim, K.-H., Jahan, S. A., Kabir, E., \& Brown, R. J. C. (2013). A review of airborne polycyclic aromatic hydrocarbons (PAHs) and their human health effects. Environment International, 60, 71-80. doi:10.1016/j.envint.2013.07.019

Crossref $\bullet$ PubMed $\bullet$ Google Scholar

Kolhatkar, A., Ochei, J., \& McGraw, T. (2008) Medical Laboratory Science: Theory and Practice, Tata Mcgraw Hill, New York, NY, USA.

Google Scholar

Larson, T. V., \& Koenig, J. Q. (1994). Wood smoke: emissions and non-cancer respiratory effects. Annual Review of Public Health, 15(1), 133-156. doi:10.1146/annurev.pu.15.050194.001025 Crossref $\bullet$ PubMed $\bullet$ Google Scholar

Mamuya, S. H., Bråtveit, M., Mashalla, Y., \& Moen, B. E. (2007). High prevalence of respiratory symptoms among workers in the development section of a manually operated coal mine in a developing country: A cross sectional study. BMC Public Health, 7(1). doi:10.1186/14712458-7-17

Crossref $\bullet$ PubMed $\bullet$ PMC $\bullet$ Google Scholar

ISSN 1996-4536 (print) • ISSN 2311-0783 (on-line) • Біологічні Студії / Studia Biologica • 2021 • Том 15 / № 4 • С. 25-36 
Monzer, B., Sepetdjian, E., Saliba, N., \& Shihadeh, A. (2008). Charcoal emissions as a source of $\mathrm{CO}$ and carcinogenic $\mathrm{PAH}$ in mainstream narghile waterpipe smoke. Food and Chemical Toxicology, 46(9), 2991-2995. doi:10.1016/j.fct.2008.05.031

Crossref • PubMed • Google Scholar

Morton, J., \& Snider, T. A. (2017). Guidelines for collection and processing of lungs from aged mice for histological studies. Pathobiology of Aging \& Age-Related Diseases, 7(1), 1313676. doi:10.1080/20010001.2017.1313676

Crossref $\bullet$ PubMed $\bullet$ PMC $\bullet$ Google Scholar

Ramesh, A., Inyang, F., Lunstra, D. D., Niaz, M. S., Kopsombut, P., Jones, K. M., Hood, D. B., Hills, E. R., \& Archibong, A. E. (2008). Alteration of fertility endpoints in adult male F-344 rats by subchronic exposure to inhaled benzo(a)pyrene. Experimental and Toxicologic Pathology, 60(4-5), 269-280. doi:10.1016/j.etp.2008.02.010

Crossref • PubMed • PMC • Google Scholar

Ramos, K. S., \& Moorthy, B. (2005). Bioactivation of polycyclic aromatic hydrocarbon carcinogens within the vascular wall: implications for human atherogenesis. Drug Metabolism Reviews, 37(4), 595-610. doi:10.1080/03602530500251253

Crossref $\bullet$ PubMed $\bullet$ Google Scholar

Reitman, S., \& Frankel, S. (1957). A colorimetric method for the determination of serum glutamic oxalacetic and glutamic pyruvic transaminases. American Journal of Clinical Pathology, 28(1), 56-63. doi:10.1093/ajcp/28.1.56

Crossref • PubMed • Google Scholar

Rengarajan, T., Rajendran, P., Nandakumar, N., Lokeshkumar, B., Rajendran, P., \& Nishigaki, I. (2015). Exposure to polycyclic aromatic hydrocarbons with special focus on cancer. Asian Pacific Journal of Tropical Biomedicine, 5(3), 182-189. doi:10.1016/s2221-1691(15)30003-4 Crossref $\bullet$ Google Scholar

Sette, L., \& Lopes, E. (2015). The reduction of serum aminotransferase levels is proportional to the decline of the glomerular filtration rate in patients with chronic kidney disease. Clinics, 70(5), 346-349. doi:10.6061/clinics/2015(05)07

Crossref $\bullet$ Google Scholar

Silva, B. O., Adetunde, O. T., Oluseyi, T. O., Olayinka, K. O., \& Alo, B. I. (2011). Effects of the methods of smoking on the levels of polycyclic aromatic hydrocarbons (PAHs) in some locally consumed fishes in Nigeria. African Journal of Food Science, 5(7), 384-391. Google Scholar

Tzanakis, N., Kallergis, K., Bouros, D. E., Samiou, M. F., \& Siafakas, N. M. (2001). Short-term effects of wood smoke exposure on the respiratory system among charcoal production workers. Chest, 119(4), 1260-1265. doi:10.1378/chest.119.4.1260

Crossref $\bullet$ PubMed $\bullet$ Google Scholar

Ubogu, M., \& Odokuma, L. O. (2019). Growth and tolerance evaluation of selected plants to crude oil contamination in the Niger Delta. Kuwait Journal of Science, 46(4), 93-103.

Google Scholar

United States Environmental Protection Agency (USEPA), (1984). Carcinogen assessment of coke oven emissions, the United States Environmental Protection Agency, Washington, D.C. Google Scholar

Xia, Y., Zhu, P., Han, Y., Lu, C., Wang, S., Gu, A., Fu, G., Zhao, R., Song, L., \& Wang, X. (2009). Urinary metabolites of polycyclic aromatic hydrocarbons in relation to idiopathic male infertility. Human Reproduction, 24(5), 1067-1074. doi:10.1093/humrep/dep006

Crossref $\bullet$ PubMed $\bullet$ Google Scholar

Zaneveld, L. J., \& Polakoski, K. L. (1977). Collection and physical examination of the ejaculate. In: E. S. Hafez (Ed.), Techniques of human andrology (pp. 147-156). North Holland Biomedical Press, Armsterdam.

Google Scholar

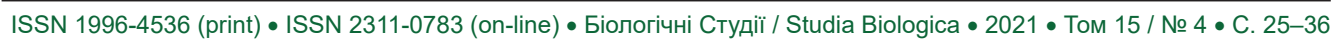




\title{
БІОХІМІЧНІ ТА ГІСТОЛОГІЧНІ ЗМІНИ У ЩУРІВ-АЛЬБІНОСІВ У ВІДПОВІДЬ НА ВПЛИВ ПИЛУ ДЕРЕВНОГО ВУГІЛЛЯ
}

\author{
О. Е. Оріакпоно ${ }^{1 *}$, С. Ануфоро ${ }^{2}$, Е. Е. Ндуонофіт ${ }^{1}$, В. К. Дія ${ }^{1}$, М. С. Екеке
}

1 Університет Порт-Харкорта, Р. М. В. 5323, Порт-Харкорт, uтат Ріверс, Нігерія ${ }^{2}$ Інститут біохімії, молекулярної біології та біотехнології, Університет Коломбо, Шрі-Ланка

Вступ. У країнах, що розвиваються, й у слаборозвинених країнах виробництво деревного вугілля супроводжується великою кількістю вугільного пилу. Працівники в цій галузі не захищені належним чином і як такі піддаються впливу вугільного пилу через вдихання та контакт зі шкірою. Деревне вугілля складається з багатьох компонентів, таких як поліциклічні ароматичні вуглеводні. Через імовірний ризик для здоров'я, пов'язаний із таким впливом, це дослідження було розроблено для визначення впливу порошку деревного вугілля з розміром частинок 125-150 мкм на певні біомаркери у самців щурів-альбіносів. Щурів-альбіносів використовували через їхню схожу з людьми фрізіологію.

Матеріали та методи. Для цього дослідження було використано двадцять щурів-альбіносів вагою від 250 до 300 г; їх випадковим чином розподілили по чотирьох групах (по 5 щурів у кожній), а порошок деревного вугілля додали до їхнього корму з різним відсотком; контроль, група 1 (10 \% деревного вугілля), група 2 (30 \% вугілля) і група 3 (підстилка з порошку деревного вугілля) протягом 50 днів. Використовуючи стандартні процедури та методи, перевіряли такі параметри: гематологічні показники, параметри сперми, ензими печінки, функцію нирок, гормони та гістологію легенів.

Результати. Результати свідчать про зниження рівня печінкових ензимів AST (Од/л) та ALT (Од/л) у групі 1, групі 2 та групі 3 порівняно з контролем з найнижчим значенням 48,75 мОд/л та 11,50 мОд/л відповідно, зареєстрований у групі 2. Пролактин (мОд/л) мав середні значення 1,73, 1,30 і 1,83 у групі 1, групі 2 та групі 3 відповідно, тоді як контроль становив 2,10. Тестостерон (нмоль/л) мав середнє значення 1,18, 0,53 та 0,25 у групі 1 , групі 2 та групі 3 відповідно, тоді як контроль становив 0,90 зі значною різницею $(P<0,05)$. Креатинін (мкмоль/л) підвищувався у групі 1 та групі 2 з незначним зменшенням у групі 3 порівняно з контролем $(1,04)$ із значенням $1,35,1,40$ та 1,23 відповідно. Загальна кількість сперматозоїдів ( $\times 10^{5} /$ мл) мала середнє значення $58,33,50,00$ та 43,25 у групі 1 , групі 2 та групі 3 відповідно, тоді як контроль становив 100,50. Гістологія легенів для оброблених груп виявила інфільтрацію запальних клітин і потовщення міжальвеолярних стінок.

Висновки. Тривалий вплив пилу деревного вугілля назальним або ротовим шляхом мав серйозні наслідки для здоров'я щурів, такі як ушкодження нирок, запалення легенів і зниження фертильності у самців, головно через наявність поліциклічних ароматичних вуглеводнів у вугіллі.

Ключові слова: деревне вугілля, гормони, безпліддя, запалення легень, поліароматичний вуглеводень

Received / Одержано 13 September, 2021
Revision / Доопрацьовано 18 November, 2021
Accepted / Прийнято 24 December, 2021
Published / Опубліковано 29 December, 2021

ISSN 1996-4536 (print) • ISSN 2311-0783 (on-line) • Біологічні Студії / Studia Biologica • 2021 • Том 15 / № 4 • С. 25-36 